doc. dr. sc. Irena Pandža Bajs

Ekonomski fakultet Zagreb, Sveučilište u Zagrebu, Zagreb, Republika Hrvatska ipandza@efzg.hr

\title{
ODREDNICE UPRAVLJANJA MARKETINGOM TURISTIČKE DESTINACIJE
}

Primljen: 23. travnja 2019.

Prihvaćen: 30. rujna 2019.

\section{Prethodno priopćenje}

\section{Sažetak}

Uspješno upravljanje marketingom turističkih destinacija rezultira pružanjem vrijednosti turističke destinacije kakvu turisti očekuju i žele što dalje vodi visokoj razni zadovoljstva i pozitivnim namjerama budućih ponašanja u kontekstu ponovnog dolaska ili preporuka prijateljima i obitelji da posjete tu destinaciju. Za svaku destinaciju važno je utvrditi kako turist percipira vrijednost njezine turističke ponude u svojoj savjesti te koji to čimbenici ponude određuju razinu percipirane vrijednosti kod njezinih trenutnih i potencijalnih turista. Analiza tih čimbenika daje smjernice kako poboljšati postojeću turističku ponudu te kako treba izgledati ponuda u budućnosti koja bi s povećanjem percipirane vrijednosti utjecala i na poboljšanje zadovoljstva tih turista i ostvarivanje čvršćih i dugoročnijih veza s njima. Svrha rada je sustavna analiza relevantnih dosadašnjih spoznaja i pristupa utvrđivanja percipirane vrijednosti za turista, njegovog zadovoljstva i namjera budućeg ponašanja, što rezultira marketinškim modelom $i$ smjernicama za kreiranje uspješne marketinške strategije turističke destinacije.

Ključne riječi: marketing turističke destinacije, percipirana vrijednost, zadovoljstvo, lojalnost

JEL: Z3 


\section{UVOD}

Marketing je društveni i upravljački proces kojim putem stvaranja, ponude i razmjene vrijednosti s drugima, pojedinci i grupe dobivaju ono što im je potrebno ili što žele (Kotler, 2001, 9). Na temelju ovakvog objašnjenja marketinga može se reći da na jednoj strani potrebe i želje pojedinaca ili grupe kreiraju potražnju za određenim vrijednostima izraženim kroz proizvode ili usluge, a na drugoj strani ponuđači nastoje ostvariti transakciju i u razmjeni dobiti one vrijednosti koje će im omogućiti uspjeh na tržištu i ostvarenje njihovih ciljeva. Zbog procesa globalizacije i pojave sve većeg broja konkurenata na tržištu, najveći problem za tvrtku predstavlja kako pridobiti potrošača da odabere baš tu ponudu koju tvrtka nudi na tržištu. Rješenje problema može se naći u kreiranju, isporuci i komuniciranju ponude koja najviše odgovara željama i zahtjevima potrošača i čija je percipirana vrijednost za potrošača veća od vrijednosti ponude drugih konkurenata. Isporuka takve vrijednosti rezultira zadovoljstvom potrošača te stvara temelje za izgradnju dugoročnih odnosa između potrošača i tvrtke.

Iako se koncept percipirane vrijednosti intenzivno istražuje više od dvadeset godina, postoje djelatnosti u kojima nije dovoljno istraženo kako potrošač percipira vrijednost određene tržišne ponude, koji čimbenici najviše utječu na njegovu percepciju, te kako se to odražava na njegovo ukupno zadovoljstvo i namjere budućeg ponašanja. Jedno od tih nedovoljno istraženih područja je i percipirana vrijednost turističke destinacije. Budući da je turizam vrlo važan aspekt gospodarskog djelovanja Hrvatske (UNWTO, 2011) onda je svakako važno usmjeriti pažnju i na analizu percipirane vrijednosti koju turisti imaju o hrvatskim turističkim destinacijama. Sustavnim pregledom relevantnih teorijskih i empirijskih spoznaja ovaj rad kreira podlogu i daje smjernice za istraživanje percipirane vrijednosti u okviru marketinga turističke destinacije.

Turistička destinacija ujedinjuje skup proizvoda i usluga koji se nude na određenoj lokaciji i zajedno čine turistički proizvod koji se nudi na svjetskom turističkom tržištu. Prema Boranić-Živoder (2009) skup komponenti destinacije kao što su atrakcije, dostupnost, receptivni sadržaji, aktivnosti, pomoćne usluge, čine ponudu turističke destinacije odnosno turistički proizvod koji se prodaje na turističkom tržištu. Zbog složene strukture i kompleksne ponude turističke destinacije, određivanje percipirane vrijednosti destinacije predstavlja izuzetno zahtjevan proces. Prema Cromptonu (1992) je za učinkovito pozicioniranje destinacije nužno prvo identificirati čimbenike koje posjetitelji percipiraju važnim, a zatim prepoznati jedinstvene karakteristike destinacije koje diferenciraju konkretnu turističku destinaciju od ostalih konkurenata. Prema tome, utvrđivanje čimbenika koji definiraju percepciju turista o turističkoj destinaciji je od ključne važnosti za kreiranje destinacijske ponude upravo onakvom kakvu je turisti žele. 
Marketinški program destinacije oblikovan prema čimbenicima koje turisti najviše vrednuju rezultirat će konkurentskom prednosti u odnosu na ostale konkurentske destinacije.

Na temelju svojih preferencija i željene vrijednosti (Van der Haar, Kemp i Omta, 2001) turist odabire destinaciju koju će posjetiti, uzimajući u obzir čimbenike očekivane koristi i očekivanih troškova. Tijekom posjeta u njegovoj se svijesti stvara percepcija vrijednosti konkretne destinacije te je konačni rezultat posjeta zadovoljstvo ili nezadovoljstvo tom turističkom destinacijom. Ako vrijednost koju turist percipira tijekom i nakon posjeta nije manja od očekivanja koja je imao, te ako su realizirane koristi veće od ostvarenih troškova, rezultat je zadovoljstvo (Woodruff i Gardial, 1996) turističkom destinacijom što dalje može potaknuti želju da dođe opet na istu destinaciju ili da drugima prenese svoja pozitivna iskustva s putovanja. Budući da je broj destinacija koje se natječu za privlačenje turista izuzetno velik, određena turistička destinacija mora ponuditi upravo onu vrijednost koju njezin ciljani segment turista želi kako bi ojačala i poboljšala svoju poziciju na tržištu.

Percipirana vrijednost za potrošača, zadovoljstvo i lojalnost su dimenzije od ključne važnosti za uspjeh i profitabilnost svake tvrtke, a definiranje modela percipirane vrijednosti i međusobnog odnosa čimbenika vrijednosti predstavlja glavnu odrednicu upravljanja marketingom u današnjim tržišnim okolnostima. Dakle, može se zaključiti da kreiranje modela čimbenika percipirane vrijednosti turističke destinacije i njihovih odnosa s marketinškim konceptima vrijednosti, zadovoljstva i poslijekupovnih namjera čini osnovu kreiranja strategije pozicioniranja destinacije na tržištu te oblikovanje marketinškog miksa turističke destinacije.

\section{NAJVAŽNIJE ODREDNICE UPRAVLJANJA MARKETINGOM TURISTIČKE DESTINACIJE}

\subsection{Percipirana vrijednost za turista kao glavna odrednica upravljanja marketingom turističke destinacije}

Percipirana vrijednost za potrošača je koncept koji daje uvid kako potrošači percipiraju proizvod ili uslugu i daje smjernice kako ga „pomladiti“ i oblikovati prema željama potrošača. Općenito se percipirana vrijednost za potrošača može definirati kao osobna, kognitivno-afektivna procjena vrijednosti ponude na tržištu u procesu kupnje bazirana na usporedbi koristi i troškova koji proizlaze iz te ponude i ponuda drugih konkurenata na tržištu $i$ koja varira s promjenom okolnosti, vremena i mjesta situacije u kojoj se donosi ta procjena. U kontekstu turističke destinacije percipirana vrijednost za turista bi bila procjena vrijednosti 
ponude turističke destinacije bazirana na odnosu percipiranih koristi i troškova koji proizlaze iz ponude te turističke destinacije kao i drugih destinacija. Značajke kao što su prirodno okruženje, kultura, povijesno nasljeđe, klima i ostale primarne značajke (čistoća plaža, dostupnost atrakcija) i koristi koje proizlaze iz korištenja tih značajki mogu biti osnovne odrednice u definiranju vrijednosti destinacije za turista, ali također i kvaliteta turističkih usluga, ponašanja pružatelja usluga i njihova učinkovitost i ljubaznost može imati odlučujući utjecaj (Yuksel, 2001) te cijena usluga i trošak putovanja. U procjeni vrijednosti vrlo važnu, ako ne i odlučujuću, ulogu mogu imati emocionalne koristi (Sanchez, Callarisa, Rodriguez i Moliner, 2006) dolaska i boravka u destinaciji - uživanje, opuštanje, doživljaj nečeg novog i slično. Znači, može se reći da se procjena vrijednosti za turista bazira na odnosu funkcionalnih i emocionalnih koristi i ukupnih troškova percipiranih prije, za vrijeme i nakon boravka u destinaciji.

Turist percipira vrijednost ako su koristi koje je dobio tijekom putovanja veće od troškova koje je uložio za taj put (Williams i Soutar, 2009). On procjenjuje je li dobiveno vrijedno uloženog novca, truda i vremena, a to dalje utječe na njegovo zadovoljstvo i namjere ponovnog dolaska na destinaciju (Lee, Yoon i Lee, 2007). Koje će koristi tražiti i kako će procjenjivati troškove ovisi o tome koje značajke i koristi turističke destinacije turist smatra važnim za svoju procjenu. Važnost pojedinih značajki i koristi razlikuju se od turista do turista s tim da pripadnici istih ciljnih skupina imaju slično ponašanje i slična mjerila vrijednosti. Istraživanje turista različitih po spolu, dobi, veličini mjesta stanovanja i učestalosti putovanja (Gallarza i Gil, 2008) je pokazalo da postoje značajne razlike u percepciji vrijednosti turista koji se razlikuju prema spomenutim karakteristikama. To je važno uzeti u obzir prilikom procesa segmentacije i odabira ciljnih skupina. Zbog toga je potrebno razvoj i implementaciju marketinškog programa turističke destinacije oblikovati prema onim ciljnim skupinama turista čije se želje i potrebe mogu najbolje ostvariti pružanjem izvrsne vrijednosti putovanja na tu destinaciju. Važno je naglasiti da se pod pojmom vrijednosti putovanja podrazumijeva i prijevoz do destinacije i boravak u destinaciji. To je potrebno istaknuti budući da turist može percipirati visoke koristi od boravka u destinaciji, ali da vrijeme i novac utrošen na put umanje ukupnu percipiranu vrijednost i smanje vjerojatnost ponovnog dolaska u destinaciju.

Turistička destinacija se može sastojati od velikog broja različitih značajki i usluga od čega turisti ne moraju doživjeti i konzumirati sve već samo one koje zadovoljavaju njegove želje i potrebe. Na taj način on kreira svoj turistički proizvod čiju vrijednost u konačnici i procjenjuje. Budući da se turistički proizvod sastoji od velikog broja različitih značajki i usluga, postavlja se pitanje proizlazi li percipirana vrijednost za turista iz ukupne procjene vrijednosti tih različitih usluga. Što ako je neka usluga pružila visoku vrijednost, a neka ne? Utječu li različite 
vrijednosti svih korištenih usluga na ukupnu vrijednost turističkog proizvoda? Za razliku od zadovoljstva kao tematike, u dostupnoj se literaturi ovom problematikom još nitko nije bavio. Pa ipak, možda se može reći da turist doživljenu vrijednost oblikuje na temelju procjene najvažnijih značajki i usluga na način da ,zbroji“ koristi proizašle iz njih i usporedi ih s ukupno uloženim troškovima putovanja i boravka u destinaciji. Uz funkcionalni aspekt koristi važnu ulogu ima emocionalni doživljaj boravka u destinaciji, kao npr. osjećaj sreće i opuštanja, jer za neke turiste taj emocionalni doživljaj može biti i glavna odrednica procjene vrijednosti.

Kako bi se bolje razumjela percipirana vrijednost za turista, nužno je utvrditi koji čimbenici destinacije imaju najveću važnost za percepciju. Sanchez, Callarisa, Rodiguez i Moliner (2006) izdvajaju funkcionalni aspekt kvalitete usluga i njihove cijene, emocionalni odgovor i socijalnu dimenziju pri oblikovanju ukupne vrijednosti konzumiranja turističkog aranžmana. U svom istraživanju, Lee, Yoon i Lee (2007) su utvrdili da na procjenu turista, njihovo zadovoljstvo i lojalnost značajan utjecaj imaju funkcionalni aspekt kvalitete i cijene boravka u destinaciji i emocionalni doživljaj turista. Jamal, Othman i Maheran (2011) su prilikom mjerenja vrijednosti jednog specifičnog oblika turizma (engl.'community-based homestay tourism') utvrdili da na percipiranu vrijednost turista utječu funkcionalna korist smještaja i okruženja, funkcionalni aspekt cijene boravka, emocionalni doživljaj uživanja i doživljaj novog iskustva, iskustveni odnos između turista i domaćina i iskustveni doživljaja kulture, aktivnosti i novih spoznaja. Oni u svom istraživanju uvode iskustvenu dimenziju vrijednosti praveći razliku između te i funkcionalne dimenzije. Funkcionalna dimenzija predstavlja procjenu izvedbe proizvoda ili usluge, dok iskustvena proizlazi (Mathwick, Malhotra i Rigdon, 2001) iz interakcije s proizvodom ili uslugom odnosno iskustva korištenja i iskustva zabave. Gallarza i Gill Saura (2006) su istraživali kako studenti kao ciljna skupina procjenjuju vrijednost zadnje destinacije koju su posjetili. Tim istraživanjem su utvrdili da na percipiranu vrijednost destinacije najviše utječu percipirana kvaliteta usluga realiziranih u destinaciji, socijalni element posjeta, zabava, izgled destinacije i trošak vremena i napora za dolazak na destinaciju. Murphy, Pritchard i Smith (2000) su pokazali da percipiranu vrijednost turističke destinacije oblikuje prvenstveno iskustvo s turističkim uslugama, a utjecaj ima i iskustvo turista s elementima okruženja destinacije.

Gallarza i Gill Saura (2006) su razvile ljestvicu mjerenja percipirane vrijednosti turističke destinacije prema općeprihvaćenoj definiciji odnosa koristi i troškova tako što su mjerili kako pozitivne (koristi) tako i negativne dimenzije (troškovi) vrijednosti turistovog doživljaja destinacije. Prema njima percipirana vrijednost je jedinstven konstrukt odnosa dobivenog u odnosu na uloženo na koji utječu efikasnost, kvaliteta usluge, zabava, izgled i socijalna dimenzija kao koristi te 
novčani troškovi, percipirani rizik i utrošak vremena i napora kao troškovi (Tablica 1).

Tablica 1. Mjerenje percipirane vrijednosti destinacije

\begin{tabular}{|c|c|}
\hline Dimenzije & Značajke \\
\hline Efikasnost & $\begin{array}{ll}\text { - } & \text { informacije dobivene tijekom putovanja (mape, raspored } \\
\text { aktivnosti) } \\
\text { - } & \text { infrastruktura u destinaciji } \\
\text { - } & \text { gastronomija u destinaciji } \\
\text { - } & \text { raspoloživost objekata za šoping u destinaciji } \\
\text { - } & \text { smještaj u destinaciji }\end{array}$ \\
\hline Kvaliteta usluga & $\begin{array}{ll}\text { - } & \text { pouzdano i dosljedno pružanje usluge } \\
\text { - } & \text { pružanje usluge na vrijeme } \\
\text { - } & \text { kompetentno turističko osoblje (znanje i sposobnosti) } \\
\text { - } & \text { turističko osoblje s kojima je lako uspostavit kontakt } \\
\text { - } & \text { ljubazno i uljudno turističko osoblje } \\
\text { - } & \text { turističko osoblje me sluša i međusobno se razumijemo } \\
\text { - } & \text { turističko osoblje je pouzdano } \\
\text { - } & \text { turističko osoblje se trudi razumjeti moje potrebe } \\
\text { - } & \text { turističko osoblje je uredno i čisto }\end{array}$ \\
\hline Zabava & $\begin{array}{ll}\text { - } & \text { uživao/la sam u odmoru (klubovi, kafići...) } \\
\text { - } & \text { uživao/la sam u slobodnom vremenu } \\
\text { - } & \text { odmor je bio ugodan } \\
\text { - } & \text { zabavio/la sam se u destinaciji }\end{array}$ \\
\hline Izgled & $\begin{array}{ll}\text { - } & \text { ljepota okruženja (planine, plaže...) } \\
\text { - } & \text { grad, gradske ulice, zgrade } \\
\text { - } & \text { muzeji, izložbe, koncerti } \\
\text { - } & \text { ljepota spomenika }\end{array}$ \\
\hline Socijalna vrijednost & $\begin{array}{ll}\text { - } & \text { učvršćuje moj osjećaj pripadanja grupi } \\
\text { - } & \text { biti socijalno prihvaćen od strane grupe } \\
\text { - } & \text { odnos s drugim turistima izvan grupe } \\
\text { - } & \text { odnos sa stanovnicima } \\
\end{array}$ \\
\hline Novčani trošak & $\begin{array}{ll}\text { - } & \text { ukupni troškovi putovanja } \\
\text { - } & \text { cijena povratne karte } \\
\text { - } & \text { cijene u destinaciji (hrana, šoping) } \\
\text { - } & \text { oportunitetni trošak }\end{array}$ \\
\hline
\end{tabular}




\begin{tabular}{|l|ll|}
\hline Percipirani rizik & - & strah od terorističkog napada tijekom boravka \\
& - & rizik da se ne bude žrtva nekog zločina tijekom boravka \\
& - & strah od bolesti \\
& - & strah od elementarnih nepogoda \\
& - & strah od bilo koje vrste nesreće \\
& - & strah od političkih i socijalnih nereda \\
& - & rizik da ne bude žrtva prevare \\
& - & rizik od lošeg odnosa stanovništva \\
\hline Utrošak vremena & i & utrošak vremena za planiranje i pripremu putovanja \\
napora & - & vrijeme utrošeno na put do destinacije i nazad \\
& - & oportunitetni trošak vremena uloženog u putovanje \\
& - & napor učinjen da se ostave svakodnevne aktivnosti \\
& - & psihički napor odvajanja od prijatelja i obitelji \\
\hline
\end{tabular}

Izvor: Gallarza, M.G., Gil Saura, I. (2006) Value dimensions, perceived value, satisfaction and loyalty: an investigation of university students' travel behaviour, Tourism Management, No. 27, 437-452.

\subsection{Zadovoljstvo turističkom destinacijom}

Kad turist posjeti određenu turističku destinaciju on se susreće s različitim značajkama destinacije kao što su izgled i prirodno okruženje destinacije, kultura, povijesno naslijeđe, klima, ali i s turističkim uslugama koje zadovoljavaju svakodnevne potrebe i želje turista (Laws, 1995). Na temelju odnosa i iskustva s tim značajkama i uslugama turist razvija osjećaj zadovoljstva ili nezadovoljstva svojim boravkom u destinaciji (Yuksel, 2001; Williams i Soutar, 2009). Znači, ukupno zadovoljstvo ljetovanjem u određenoj destinaciji dolazi od lijepog prirodnog okruženja, zanimljivih atrakcija, klime, ali i od kvalitete dobivenih usluga, ponašanja ljudi s kojima se susreću, odnosa i ljubaznosti zaposlenika prema turistu i njihova spremnost da brzo riješe sve upite i probleme turista (Yuksel i Yuksel, 2001).

World Tourism Organization (1985, u Pizam i Ellis, 1999) definira zadovoljstvo kao psihološki koncept koji podrazumijeva osjećaje dobrobiti i uživanja, a koji su rezultat dobivanja onog što se želi i očekuje od određenog proizvoda ili usluge. U kontekstu putovanja zadovoljstvo je, znači, rezultat odnosa između očekivanja prije putovanja i turističkog doživljaja putovanja, odnosno rezultat putovanja na destinaciju u odnosu na prethodna očekivanja. Prema vrijednosnoj teoriji mjerenja zadovoljstva, zadovoljstvo turističkom destinacijom može se promatrati kao 
usporedba između očekivane vrijednosti s vrijednošću dobivenom tijekom boravka u destinaciji (Sanchez, Callarisa, Rodriguez i Moliner, 2006).

U kontekstu ovakvog definiranja zadovoljstva boravkom na turističkoj destinaciji, postavlja se pitanje može li se zaista tako definirati zadovoljstvo turista budući da zadovoljstvo može biti rezultat različitih iskustava koje turist uopće nije ni očekivao (Troung i Foster, 2006). Međutim, istraživanja percepcije i motivacije su pokazala da očekivanja imaju značajnu ulogu za motivaciju i odabir konkretnog putovanja pa su tako i važni za procjenu iskustva boravka u destinaciji. Imidž destinacije, atrakcije, prirodno okruženje destinacije, informacije o destinaciji, prethodna iskustva s tom i drugim destinacijama oblikuju najveći dio očekivanja na kojima se temelji procjena iskustva destinacije (Troung i Foster, 2006). Neočekivana iskustva mogu povećati ili umanjiti konačno zadovoljstvo ovisno od toga radi li se o pozitivnim ili negativnim iskustvima.

Turistička destinacija je kompleksan proizvod pa je i zadovoljstvo turista složen konstrukt. Za razliku od pojedinačnih proizvoda i usluga, većina turističkih iskustava predstavlja jedinstvo različitih značajki destinacije i usluga s kojima se turist susreće na turističkoj destinaciji. Svaka se usluga koju turist primi tijekom boravka može promatrati kao skup značajki koje se procjenjuju kako bi se oblikovao stav o zadovoljstvu tom uslugom (Pizam i Ellis, 1999). Na primjer, usluga u restoranu se može analizirati kroz kvalitetu hrane i pića u restoranu, ponašanju i odnosu osoblja koje poslužuje, te interijera i atmosfere u restoranu. Sukladno tome se zadovoljstvo turističkom destinacijom može promatrati kao suma zadovoljstva sa značajkama destinacije i uslugama konzumiranim u destinaciji (Chi i $\mathrm{Qu}, 2008)$. Odnosno, zadovoljstvo smještajem, hranom, atrakcijama, prirodnim okruženjem, vremenom i slično, vodi ukupnom zadovoljstvu turista svojim putovanjem na destinaciju. S obzirom na to da se može raditi o velikom broju značajki i usluga, postavlja se pitanje kako se određuje ukupno zadovoljstvo turista? Ako je nekim uslugama zadovoljan, a drugima nije, kako procjenjuje ukupno zadovoljstvo? Formira li set pojedinačnih dojmova za svaku uslugu i uspoređuje ih s očekivanom vrijednosti koju je imao prije posjeta? Je li ukupna razina zadovoljstva rezultat sume svih dojmova?

Pizam i Ellis (1999) su u svom radu objasnili zadovoljstvo kao rezultat različitih modela ponašanja. Prema kompenzacijskom modelu ponašanja pretpostavka je da korisnik prilikom procjene proizvoda ili usluge nalazi kompromis između različitih čimbenika kako bi donio odluku (Pizam i Ellis, 1999). Znači, može biti nezadovoljan hotelskim smještajem, ali oduševljen prirodom i plažama pa da ukupno zadovoljstvo bude na visokoj razini. Prema nekompenzacijskom konjuktivnom modelu korisnik postavlja minimalnu razinu prihvatljivosti za svaki relevantan čimbenik i postaje zadovoljan jedino ako svaki čimbenik zadovoljava ili prelazi zadani donji prag, dok kod disjunktivnog nekompenzacijskog modela korisnik 
postavlja minimalni prag samo za jednu ili par najvažnijih značajki koje su mu najvažnije. Istraživanja provedena u sektoru turizma podržavaju disjunktivni model (Pizam i Ellis, 1999) što znači da se u razmatranje uzima par najvažnijih značajki te na temelju njihove izvedbe donosi stav o zadovoljstvu.

U kontekstu prethodno navedenih modela ponašanja i rezultata istraživanja u turizmu, zadovoljstvo turističkom destinacijom se temelji na zadovoljstvu značajkama i uslugama koje su turistu najvažnije, dok neodgovarajuća izvedba značajki i usluga koje mu nisu važne vjerojatno neće bitno utjecati na ukupno zadovoljstvo. Prema tome, može se zaključiti da se očekivanja turista oblikuju na temelju značajki i usluga destinacije koje su njemu najvažnije te da zadovoljstvo boravkom u destinaciji proizlazi iz odnosa doživljene i očekivane vrijednosti tih najvažnijih značajki. Može se reći da je ukupno zadovoljstvo boravkom u destinaciji funkcija izvedbe dimenzija vrijednosti turističke destinacije. Važno je istaknuti da različite grupe turista mogu temeljiti svoje zadovoljstvo na različitim značajkama ponude, što zahtijeva različite marketinške strategije za različite grupe turista pa tako marketinški napori za privlačenje i zadržavanje mladih turista mogu biti potpuno različiti od aktivnosti za privlačenje turista starije dobi. To znači da održavanje i unapređenje zadovoljstva ciljnih skupina turista treba temeljiti na praćenju značajki koje određuju njihovo zadovoljstvo.

Značajan broj istraživača (Pizam i Ellis, 1999; Yuksel, 2001; Gallarza i Gil Saura, 2006; Chi i Qu, 2008; Alegre i Cladera, 2009; Williams i Soutar, 2009; Williams, Soutar, Ashill i Naumann, 2017) je istraživao i mjerio komponente koje doprinose zadovoljstvu turista u različitim turističkim i uslužnim kontekstima. Prema njima na zadovoljstvo može utjecati kvaliteta usluge (Chen i Chen, 2009), percipirana vrijednost i različite dimenzije vrijednosti: funkcionalna, novčana, emocionalna, socijalna, novih spoznaja (Williams i Soutar, 2009; Williams, Soutar, Ashill i Naumann, 2017), motivi odlaska na destinaciju, broj prethodnih posjeta (Alegre i Cladera, 2009), imidž destinacije (Chi i Qu, 2008). Kvaliteta usluga i okruženje mogu biti vrlo važni motivi koji ostvaruju značajan utjecaj na zadovoljstvo. Tako, prema istraživanju Alegre i Cladera (2009) turisti koji su motivirani kvalitetom pokazuju veću razinu zadovoljstva, dok je suprotna situacija s turistima motiviranim cijenom boravka. Percipirana vrijednost za turista kao i njezine pojedine dimenzije utječu na zadovoljstvo turista, pa što je veća percipirana vrijednost boravka u destinaciji veće je i zadovoljstvo. Prema Chi i Qu (2008) zadovoljstvo turista može biti veće ako turist percipira imidž destinacije kao pozitivan.

Za mjerenje zadovoljstva boravkom u određenoj destinaciji pored općeprihvaćene ljestvice za mjerenje usluga - SERQUAL može se koristiti metoda razvijena upravo za mjerenje zadovoljstva u turizmu - HOLSAT. Svrha primjene HOLSAT ljestvice je da se odrede ključne značajke destinacije koje najviše određuju 
zadovoljstvo turista te da se procijene stavovi o tim značajkama koje generiraju zadovoljstvo ili nezadovoljstvo (Tribe i Snaith, 1998).

Ova metoda mjerenja koristi koncept očekivanja i diskonformacije u kojem potvrda očekivanja rezultira zadovoljstvom, a razlika doživljenog i očekivanog rezultira pozitivnom ili negativnom diskonformacijom (Teorija očekivanja i diskonformacije je objašnjena u trećem poglavlju rada). Znači, HOLSAT prikazuje zadovoljstvo boravkom u destinaciji kao razliku između izvedbi značajki destinacije i očekivanja turista. U mjerenje zadovoljstva se mogu uključiti i pozitivne i negativne značajke vezane za destinaciju. Tako na primjer, pozitivna značajka jedne destinacije bi mogla biti lijepe $i$ čiste plaže, a negativna značajka prevelike gužve na plaži/ u gradu i sl. Mjerenje zadovoljstva primjenom ljestvice HOLSAT omogućava prepoznavanja značajki koje ispunjavaju očekivanja turista, kao i značajki čija izvedba nije zadovoljavajuća te rezultira negativom diskonformacijom. Time se dobivaju smjernice što se treba napraviti kako bi se povećalo zadovoljstvo ponudom.

Tribe i Snaith (1998) su u svom istraživanju turističke destinacije izdvojili slijedeće dimenzije turističkog proizvoda koji određuju zadovoljstvo: (1) fizičko okruženje i oprema, (2) ambijent, (3) restorani, barovi, trgovine i noćni život, (4) transport, (5) povijesno naslijeđe i kultura, (6) smještaj. Te se dimenzije mogu koristiti za mjerenje zadovoljstva svake destinacije, ali se također u mjernu ljestvicu mogu uključiti i dodatne značajke specifične za destinaciju koja se analizirala.

\subsection{Lojalnost turističkoj destinaciji}

Lojalnost potrošača predstavlja dugoročni odnos između tvrtke i potrošača, u kojem je potrošač odan tvrtki zbog vrijednosti koju mu tvrtka isporučuje i emocionalne povezanosti s tom tvrtkom i njezinom ponudom. Osim što je u procesu kupnje potrošač lojalan tvrtki, on je spreman svojim prijateljima i obitelji prenositi svoja pozitivna iskustva i preporučivati proizvod. S marketinškog aspekta šest puta je jeftinije planirati i implementirati marketinšku strategiju za odane potrošače, nego privući nove (Petrick, 2004). Sukladno tome, s aspekta turističkog tržišta, važnost ponovnih dolazaka turista u destinaciju se očituje su tome što oni predstavljaju stabilno tržište za destinaciju, jeftinije ih je zadržati nego privući nove turiste i pružaju besplatni komunikacijski kanal u obliku preporuka prijateljima i obitelji što predstavlja jedan od najtraženijih i najpouzdanijih izvora informacija u procesu kupnje (Oppermann, 2000). Osnovni razlozi zbog kojih turisti ponovno posjećuju istu destinaciju su: smanjenje rizika vezanih za ponudu destinacije i smanjenje rizika vezanih za ljude, što znači da prethodno iskustvo sa sadržajima i ljudima u destinaciji pruža sigurnost od neugodnih situacija ili razočarenja koji se mogu dogoditi kod odlaska u nepoznatu destinaciju, zatim tu 
je emocionalna povezanost s destinacijom, motiv da dalje istražuje ponudu destinacije i pokazivanje destinacije drugim ljudima (Opperman, 2000).

Mjerenje lojalnosti se ostvaruje kroz mjerenje ponašanja potrošača, mjerenje stava prema proizvodu ili primjenom oba navedena načina. U analizi ponašanja turista lojalnost se također promatra kroz ta dva aspekta: ponašanje turista i stav prema turističkoj destinaciji. $\mathrm{S}$ aspekta ponašanja ponovljeni dolasci i češći dolazak u turističku destinaciju su indikator lojalnosti, a kroz pozitivno mišljenje i preporuke drugima se očituje stav turista prema turističkom proizvodu. Budući da je turistički proizvod znatno drugačiji od fizičkog proizvoda, ponovni dolasci u destinaciju ne moraju biti prava mjera lojalnosti turističkoj destinaciji pa pojedini autori (Chen i Gursoy, 2001) postavljaju pitanje je li ponovno dolaženje na istu destinaciju prava mjera lojalnosti. Razlog tome je što pojedini turisti žele istraživati nove destinacije u potrazi za novim iskustvima pa se ne vraćaju u destinacije koje su već posjetili bez obzira na razinu vrijednosti i zadovoljstva koje su tamo doživjeli. Stoga je važno utvrditi kakav stav turist ima o destinaciji pa će oni s pozitivnim stavom, čak i ako neće više posjetiti destinaciju, drugima preporučivati da je posjete (Oppermann, 2000).

Odluka o ponovnom dolasku u destinaciju ovisi o velikom broj čimbenika kao što su motivi dolaska (Alegre i Cladera, 2009), zadovoljstvo boravkom i percipirana vrijednost za turista (Petrick, Morais i Norman, 2001; Chen i Chen, 2009), prethodna iskustva s destinacijom (Oppermann, 2000; Chen i Gursoy, 2001; Petrick, Morais i Norman, 2001; Petrick, 2004; Alegre i Cladera, 2009), imidž destinacije (Chi i Qu, 2008). Motivi putovanja mogu utjecati na buduće ponašanje turista, pa tako odabir destinacije koji se temelji na cijeni putovanja može imati negativan utjecaj na namjere ponovnog dolaska što se nadovezuje na stav da su potrošači koji svoj izbor temelje na cijeni više otvoreni za druge opcije konkurenata (Alegre i Cladera, 2009). Istraživanja utjecaja zadovoljstva na namjere turista da ponovno posjete destinaciju ili je preporuče drugima (Baker i Crompton, 2000; Petrick, Morais i Norman, 2001, Petrick, 2004; Alegre i Cladera, 2009) su potvrdila da postoji direktna pozitivna veza između tih veličina. Doživljena vrijednost za turista odnosno njegova percepcija dobivenih koristi u odnosu na uložene troškove također ima pozitivan utjecaj, ili preko zadovoljstva, na namjere ponovnog dolaska i preporuke drugima (Williams i Soutar, 2009). Od dimenzija vrijednosti za turista najveći utjecaj na namjere ponovnog dolaska u destinaciju mogu ostvariti emocionalna dimenzija i dimenzija novog iskustva (Williams i Soutar, 2009; Jamal, Othman i Maheran, 2011), kvaliteta usluga (Gallarza i Gill, 2006). Chi i Qu (2008) uključuju imidž destinacije kao važnu determinantu potrošačevog izbora destinacije, ali također i njegovu procjenu nakon boravka i budućih namjera ponašanja. Također, istraživanjima je potvrđeno da na namjere ponovnog dolaska utječu i prethodni dolasci na destinaciju (Petrick, Morais i Norman, 2001; 
Petrick, 2004). Pa je tako veća vjerojatnost da će ponovno doći turisti koji su bili više puta u destinaciji u odnosu na one koji prvi put dolaze (Yuksel, 2001; Alegre i Cladera, 2009) odnosno što je veći broj prethodnih posjeta, veća je vjerojatnoća da će turist doći opet. Ovakav odnos između prethodnih dolazaka i namjera ponovnog dolaska se može objasniti kroz rutinu ponašanja ili način da se izbjegne rizik od loših iskustava kroz odabir nečeg što je već provjereno. Pa čak i turisti koji nisu bili posebno zadovoljni boravkom u destinaciji mogu ponovno doći zbog elementa rizika da će negdje drugdje biti lošije. Također, kod turista koji su već bili u destinaciji manja je vjerojatnost da će postojati negativna razlika između iskustva i očekivanja.

Analizirajući značajke destinacije koje najviše utječu na namjere ponovnog posjeta, Yuksel (2001) je prepoznao kvalitetu hrane, kvalitetu usluga, gostoljubivost, plaže i okruženje kao važne značajke kod turista koji prvi put dolaze na destinaciju, dok su gostoljubivost ljudi, kvaliteta smještaja, mir, te sigurnost destinacije imale najveći utjecaj na ponovni dolazak stalnih gostiju. Chen i Gursoy (2001) su u svom istraživanju utvrdili da na lojalnost turista i njegove namjere da destinaciju preporuči drugima, utječu: sigurnost destinacije, percipirane kulturne razlike te percipirana pogodnost prijevoza.

Iz svega navedenog očito je da lojalnost turističkoj destinaciji nije jednostavno analizirati budući da se radi o složenom ,proizvodu“. Dok je za pojedine usluge u tom proizvodu moguće razviti veću lojalnost potrošača kroz različite programe lojalnosti uvođenjem kartica lojalnosti, na primjer za avionske kompanije ili lance hotela, za lojalnost turističkoj destinaciji nije moguće razviti sličan program. Lojalnost turističkoj destinaciji može biti oblikovana različitim čimbenicima, među kojima emocionalna povezanost i naklonost upravo toj destinaciji može biti važan čimbenik ponovnog izbora. Međutim, iako pojedini autori ističu da je ponašajuća komponenta odnosno ponovni dolasci u destinaciju prava mjera lojalnosti, zbog sklonosti turista da stječu nova iskustva i odlaze u različite destinacije, važna mjera lojalnosti turista može biti sklonost i namjera da prijateljima i obitelji preporuče putovanje u turističku destinaciju.

\section{MEĐUOVISNOST PERCIPIRANE VRIJEDNOSTI, ZADOVOLJSTVA I BUDUĆIH NAMJERA PONAŠANJA TURISTA}

Kada se analizira odnos koncepata percipirane vrijednosti, zadovoljstva i budućih namjera ponašanja potrošača može se utvrditi da se percipirana vrijednost često ističe kao prethodnik i ključna determinanta zadovoljstva potrošača i njihovih budućih namjera ponašanja (Cronin, Brady i Hult, 2000; McDougal i Levesque, 
2000; Parasuraman i Grewal, 2000). Woodruff (1997) ističe da su dimenzije percipirane vrijednosti prethodnici ukupnog zadovoljstva te da utječu na buduće ponašanje potrošača kao što je namjera ponovne kupnje ili preporuke drugima. Međuovisnost percipirane vrijednosti za potrošača, zadovoljstva i namjera ponašanja je analizirana i dokazana i s teorijskog i empirijskog aspekta. Teorijsku potvrdu odnosa moguće je prepoznati u opće prihvaćenoj Ajzenovoj i Fishbeinovoj (1980) teoriji ponašanja. Prema toj teoriji spoznaja vodi prema afektivnom stanju koje dalje određuje ponašanje (Gill, Byslma i Ouschan, 2007) odnosno s aspekta kupnje i ponašanja potrošača može se reći da racionalna spoznaja percipirane vrijednosti vodi prema afektivnom stanju zadovoljstva što određuje buduće ponašanje potrošača.

Analiza relevantnih istraživanja o odnosu između percipirane vrijednosti, zadovoljstva i lojalnosti u turizmu je sažeta u Tablici 2.

Tablica 2. Analiza istraživanja u turizmu

\begin{tabular}{|l|l|}
\hline Istraživači & Rezultati istraživanja \\
\hline Oh (1999) & $\begin{array}{l}\text { Istraživanje u hotelskoj industriji je pokazalo sljedeće: percipirana } \\
\text { kvaliteta usluge i cijena imaju direktan utjecaj na percipiranu vrijednost, } \\
\text { tim da utjecaj kvalitete pozitivan, a cijene negativan; percipirana vrijednost } \\
\text { direktno i indirektno preko zadovoljstva utječe na buduće namjere } \\
\text { ponašanja (ponovna kupnja i preporuke drugima). }\end{array}$ \\
\hline $\begin{array}{l}\text { Kashyap } \\
\text { and } \\
\text { Bojanic } \\
(2000)\end{array}$ & $\begin{array}{l}\text { Istraživanje analizira odnos između turistove percepcije kvalitete, cijene, } \\
\text { vrijednosti i namjere ponovnog posjeta hotelu. Rezultati pokazuju da } \\
\text { kvaliteta ima pozitivan utjecaj, dok je utjecaj cijene na percipiranu } \\
\text { vrijednost negativan, a percipirana vrijednost utječe na ponovnu posjetu } \\
\text { kako u segmentu poslovnih tako i turističkih putovanja. }\end{array}$ \\
\hline $\begin{array}{l}\text { Petrick, } \\
\text { Morais i } \\
\text { Norman } \\
(2001)\end{array}$ & $\begin{array}{l}\text { Istraživanje u sektoru turizma, turističkih putovanja, utvrdilo je da na } \\
\text { namjereponovne kupnje direktno utječu percipirana vrijednost za potrošača, } \\
\text { zadovoljstvo i iskustvo prošlih ponašanja. Utvrđeno je da zadovoljstvo } \\
\text { osim direktnog utjecaja i indirektno, preko percipirane vrijednosti, utječe } \\
\text { na namjere ponašanja. }\end{array}$ \\
\hline $\begin{array}{l}\text { Tam } \\
(2004)\end{array}$ & $\begin{array}{l}\text { Rezultati istraživanja pokazuju da percipirana kvaliteta ima direktan } \\
\text { pozitivan utjecaj na percipiranu vrijednost i zadovoljstvo, percipirani } \\
\text { trošak ima direktan negativan utjecaj na percipiranu vrijednost, percipirana } \\
\text { vrijednost ima direktan utjecaj i na zadovoljstvo i poslijekupovno } \\
\text { ponašanje, dok zadovoljstvo ima direktan utjecaj na namjere budućeg } \\
\text { ponašanja. Namjere budućeg ponašanja se mjere kroz stavove o lojalnosti, } \\
\text { ponovne kupnje, češćeg konzumiranja i preporuka drugima. }\end{array}$ \\
\hline $\begin{array}{l}\text { Petrick } \\
(2004)\end{array}$ & $\begin{array}{l}\text { Studija potvrđuje dakvaliteta,percipirana vrijednostizadovoljstvo određuju } \\
\text { buduće ponašanje turista na kruzerima. Rezultati pokazuju da je kvaliteta } \\
\text { bolji pokazatelj namjera ponovne kupnje od percipirane vrijednosti, a } \\
\text { percipirana vrijednost je bolji pokazatelj od zadovoljstva. Osim kvalitete } \\
\text { studija je analizirala i druge dimenzije vrijednosti: emocionalni aspekt, } \\
\text { financijski i nefinancijski trošak te reputaciju. }\end{array}$ \\
\hline
\end{tabular}




\begin{tabular}{|c|c|}
\hline $\begin{array}{l}\text { Gallarza i } \\
\text { Gil Saura } \\
(2006)\end{array}$ & $\begin{array}{l}\text { Prema njihovom istraživanju provedenom u turizmu percipirana vrijednost } \\
\text { direktno utječe na zadovoljstvo, a zadovoljstvo ima direktan utjecaj na } \\
\text { lojalnost potrošača mjerenu kroz namjere ponovnog korištenja i preporuka } \\
\text { drugima. Trošak usluga utječe na percipiranu vrijednost, dok kvaliteta } \\
\text { usluga utječe i na percipiranu vrijednost i lojalnost potrošača. }\end{array}$ \\
\hline $\begin{array}{l}\text { Gill, } \\
\text { Byslma i } \\
\text { Ouschan } \\
(2007)\end{array}$ & $\begin{array}{l}\text { Dimenzije koje definiraju percipiranu vrijednost (kvaliteta, cijena, socijalna } \\
\text { dimenzija) ostvaruju značajan utjecaj na zadovoljstvo potrošača te direktan } \\
\text { i indirektan utjecaj na namjere ponašanja. Istraživanje je provedeno u } \\
\text { specifičnom obliku turizma - vinarski turizam. }\end{array}$ \\
\hline $\begin{array}{l}\text { He i Song } \\
(2008)\end{array}$ & $\begin{array}{l}\text { Autori su istraživali odnos između percipirane kvalitete usluga, vrijednosti, } \\
\text { zadovoljstva i namjera ponovne kupnje paketa turističkih usluga, } \\
\text { zaključujući da kvaliteta usluga ima pozitivan utjecaj na percipiranu } \\
\text { vrijednost i zadovoljstvo; zatim percipirana vrijednost utječe na } \\
\text { zadovoljstvo dok zadovoljstvo ima direktan utjecaj na ponovnu kupnju. }\end{array}$ \\
\hline $\begin{array}{l}\text { Williams } \\
\text { i Soutar } \\
(2009)\end{array}$ & $\begin{array}{l}\text { Istraživanjem u segmentu pustolovnog turizma potvrdili su pretpostavku } \\
\text { da što je veća percipirana vrijednost, veće je zadovoljstvo potrošača i } \\
\text { pozitivnije su namjere budućeg ponašanja potrošača. Prema njima postoji } \\
\text { direktna i pozitivna veza između percipirane vrijednosti i zadovoljstva kao } \\
\text { i između percipirane vrijednosti i namjera ponašanja potrošača. Također, } \\
\text { zadovoljstvo je prepoznato i kao medijator između percipirane vrijednosti } \\
\text { i namjera ponašanja. Na buduće namjere ponašanja direktno utječu i } \\
\text { pojedine dimenzije percipirane vrijednosti (funkcionalna, emocionalna i } \\
\text { dimenzija novih spoznaja). }\end{array}$ \\
\hline $\begin{array}{l}\text { Bradley } \\
\text { i Sparks } \\
(2012)\end{array}$ & $\begin{array}{l}\text { Ovo istraživanje zaključuje da vrijednost i promjene percipirane vrijednosti } \\
\text { određuju i promjene zadovoljstva i namjera ponovne kupnje. Njihovi } \\
\text { zaključci daju potvrdu modelu pozitivnog utjecaja koncepata kvaliteta- } \\
\text { percipirana vrijednost-zadovoljstvo-namjere ponovne kupnje. }\end{array}$ \\
\hline $\begin{array}{l}\text { Gallarza, } \\
\text { Arteaga- } \\
\text { Moreno, } \\
\text { Del } \\
\text { Chiappa, } \\
\text { Gil-Saura } \\
(2016) \\
\end{array}$ & $\begin{array}{l}\text { Istraživanje analizira odnos intrinzičnih dimenzija vrijednosti (emocionalni } \\
\text { aspekt), percipirane vrijednosti, zadovoljstva i lojalnosti domaćih i stranih } \\
\text { turista u sektoru hotelijerstva. Rezultati pokazuju da zabava, relaksacija te } \\
\text { izgled kao intrinzične varijable pozitivno utječu na percipiranu vrijednost, } \\
\text { dok percipirana vrijednost ima jak pozitivan utjecaj na zadovoljstvo koje u } \\
\text { konačnici utječe na lojalnost turista. }\end{array}$ \\
\hline $\begin{array}{l}\text { Williams, } \\
\text { Soutar, } \\
\text { Ashill i } \\
\text { Naumann } \\
(2017)\end{array}$ & $\begin{array}{l}\text { Autori su istražili različite vrijednosti (funkcionalnu, novčanu, } \\
\text { emocionalnu, socijalnu i novih spoznaja) i njihov utjecaj na zadovoljstvo } \\
\text { i namjere ponašanja za specifičan oblik turizma - avanturizam. Utvrđeno } \\
\text { je da za dvije grupe turista (Zapadni vs. Istočni) cijena, emocionalna } \\
\text { vrijednost i nove spoznaje imaju značajan utjecaj na zadovoljstvo, dok } \\
\text { zadovoljstvo ima direktan utjecaj na namjere ponašanja. Za grupu Istočnih } \\
\text { turista utvrđeno je da emocionalna i socijalna vrijednost imaju direktan } \\
\text { utjecaj na namjere ponašanja, dok je kod Zapadnih turista zadovoljstvo } \\
\text { medijator između različitih vrijednosti i namjera ponašanja. }\end{array}$ \\
\hline
\end{tabular}

Izvor: obrada autora 
Na temelju prethodne analize i pregleda dosadašnjih empirijskih saznanja, oblikovan je model odnosa percipirane vrijednosti, zadovoljstva i namjera ponašanja turista koji bi mogao biti vrlo koristan za upravljanje marketingom turističke destinacije.

Slika 1. Model vrijednosti, zadovoljstva i namjera ponašanja turista

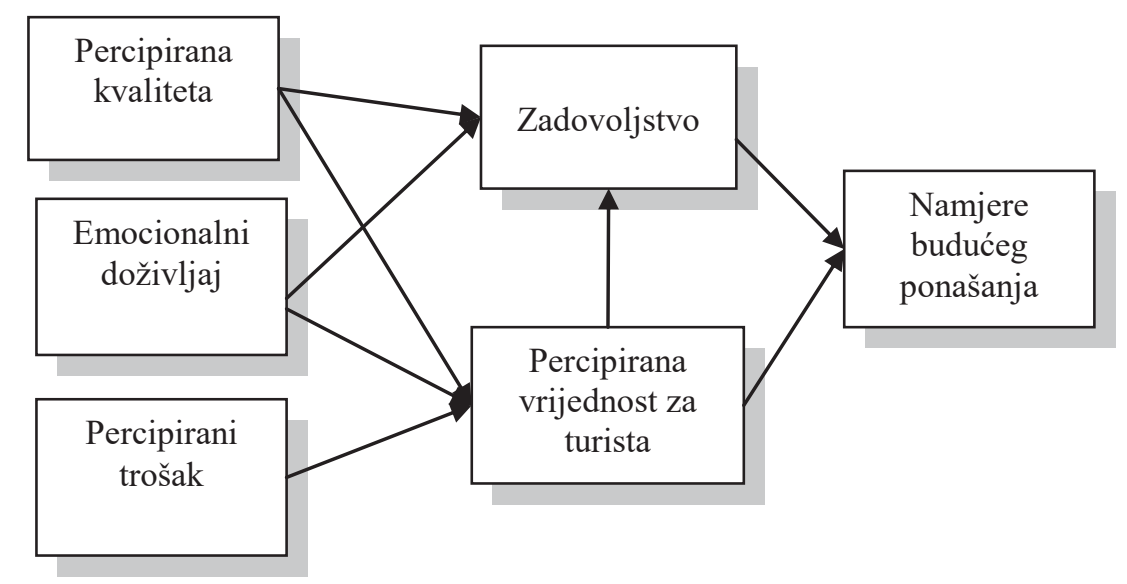

Izvor: obrada autora

Model je definiran na temelju rezultata najvećeg broja analiziranih istraživanja i prikazuje da percipirana kvaliteta i emocionalni doživljaj turista ima direktan utjecaj na percipiranu vrijednost i zadovoljstvo, dok percipirani trošak negativno utječe na percipiranu vrijednost. U tom modelu percipirana vrijednost ostvaruje kako direktan utjecaj na namjere ponašanja tako i indirektno preko zadovoljstva. Većina je istraživača utvrdila da su percipirana kvaliteta usluge, percipirani troškovi, percipirana vrijednost za potrošača i zadovoljstvo ključni faktori lojalnosti u uslužnim djelatnostima. Međutim, sva istraživanja nisu usuglašena oko toga utječe li percipirana vrijednost za potrošača na buduće namjere direktno ili indirektno preko zadovoljstva, dok su složni da zadovoljstvo direktno utječe na namjere ponovne kupnje. Sažimajući sve do sada izloženo može se zaključiti da i percipirana vrijednost za potrošača i zadovoljstvo kao rezultat odnosa dobivenog i očekivanog utječu na potrošačevo buduće ponašanje, njegove namjere ponovne kupnje i namjere da proizvod ili uslugu preporuče svojim prijateljima i obitelji. 


\section{ZAKLJUČAK}

Marketing turističke destinacije predstavlja važnu funkciju u upravljanju turističkom destinacijom. U literaturi (Laws, 1995; Ritchie i Crouch, 2003; Pike, 2004) se često isticalo kako je temelj upravljanja turističkom destinacijom planiranje i provedba marketinških aktivnosti i to prvenstveno promocije. Upravljanje turističkom destinacijom podrazumijeva planiranje, provođenje i kontrolu proaktivnih odluka što ponuditi u destinaciji, uzimajući u obzir potražnju i promjene ukusa posjetitelja destinacije s ciljem da se utječe na doživljaj i procjenu vrijednosti za turista (Pike, 2004, 10).

Svrha upravljanja destinacijom jeste planiranje i kontroliranje svih aktivnosti koje trebaju rezultirati uspjehom destinacije na turističkom tržištu. Međutim, upravljanje destinacijom uključuje i unapređenje ekonomske i socijalne dobrobiti stanovništva koje živi na toj destinaciji. To znači da upravljanje destinacijom treba omogućiti ostvarenje dobrobiti stanovništva kroz ponudu različitih turističkih aktivnosti i iskustava koje oblikuju turistički proizvod (Ritchie i Crouch, 2003, str. 185). Konzumiranjem turističkog proizvoda turist procjenjuje odnos između koristi koje je dobio i troškova koje je uložio da bi došao i boravio u destinaciji. Ponudom onih aktivnosti koje turist želi i očekuje, ostvaruje se veća vrijednost za turista čime se direktno utječe na njegovo zadovoljstvo i namjere ponovnog dolaska na destinaciju. Prema tome, mogu se izdvojiti osnovni ciljevi upravljanja turističkom destinacijom (Boranić-Živoder, 2009, 81):

- Lokalnom stanovništvu osigurati ugodnu sredinu za život.

- Poslovnom sektoru osigurati ostvarenje željenog profita.

- Turistima pružiti kvalitetan turistički proizvod i visoku vrijednost turističkog proizvoda.

S marketinškog aspekta gledano, ako se ne ponudi visoka vrijednost turistima, onda se ni ostali ciljevi upravljanja destinacijom ne mogu ostvariti. U tom slučaju turisti će manje posjećivati destinaciju što će smanjiti prihode poslovnom sektoru, ali i lokalnim jedinicama samouprave. Manja će biti ulaganja u razvoj destinacije što rezultira i stagnacijom životnog standarda u destinaciji. Stoga, percipirana vrijednost turista treba biti osnovna vodilja kreiranja turističkog proizvoda destinacije uz uvjet da se vodi računa o racionalnom korištenju javnih dobara i resursa destinacije. 


\section{LITERATURA}

1. Ajzen, I., Fishbein, M., (1980). Understanding attitudes and predicting social behavior, NJ: Prentice-Hall, Inc.

2. Alegre, J., Cladera, M. (2009). Analysing the effect of satisfaction and previous visits on tourist intentions to return, European Journal of Marketing, 43 (5/6), 670-685.

3. Baker, D.A, Crompton, J.L. (2000). Quality, satisfaction and behavioral intentions, Annals of Tourism Research, 27, 785-804.

4. Boranić-Živoder, S., (2009). Upravljanje turističkom destinacijom u funkciji održivog razvoja turizma, Doktorska disertacija, Ekonomski fakultet Zagreb

5. Bradley, Graham L., and Beverley Sparks. (2012). Antecedents and Consequences of Consumer Value: A Longitudinal Study of Timeshare Owners. Journal of Travel Research, 51 (2), 191-204.

6. Chen, C.F., Chen, F.S. (2010). Experience quality, perceived value, satisfaction and behavioral intentions for heritage tourists, Tourism Management, 31, 29-35.

7. Chen, J.S., Gursoy, D. (2001). An investigation of tourists destination loyalty and preferences, International Journal of Contemporary Hospitality Management, 13 (2), 79-85.

8. Chi, C.G., Qu, H. (2008). Examining the structural relationships of destination image, tourist satisfaction and destination loyalty: An integrated approach, Tourism Management, 29, 624-636.

9. Crompton, J.L. (1992). Structure of vacation destination choice sets, Annal of Tourism Research, 19, 420-34.

10. Cronin, J. J. Jr., Brady, M. K., Hult, G. T. (2000). Assessing the effects of quality, value, and consumer satisfaction on consumer behavioural intentions in service environment, Journal of Retailing, 76 (2), 193-218.

11. Gallarza, M., Arteaga-Moreno, F., Del Chiappa, G. Gil-Saura, I., (2016). Intrinsic value dimensions and the value-satisfaction-loyalty chain: a causal model for services, Journal of Services Marketing, 30 (2), 1-22

12. Gallarza, M.G., Gil Saura, I. (2006). Value dimensions, perceived value, satisfaction and loyalty: an investigation of university students' travel behaviour, Tourism Management, 27, 437-452.

13. Gallarza, M.G., Gil, I. (2008). The concept of value and its dimensions: a tool for analysing tourism experiences, Tourism Review, 63 (3), 4-20.

14. Gill, D., Byslma, B., Ouschan, R., (2007). Customer perceived value in a cellar door visir: the imact on behavioural intentions, International Journal of Wine Business Research, 19 (4), 257-275. 
15. He, Y., Song, H. (2008). A Mediation Model of Tourists’ Repurchase Intentions for Packaged Tour Services. Journal of Travel Research, 47 (3), 317-31.

16. Jamal, S.A., Othman, N., Maheran, N. (2011). Tourist perceived value in a community-based homestay visit. An investigation into functional and experiental aspect of value, Journal of Vacation Marketing, 17 (1), 5-15.

17. Kashyap, R., Bojanic. D. C. (2000). A Structural Analysis of Value, Quality, and Price Perceptions of Business and Leisure Travelers. Journal of Travel Research, 39, 45-51.

18. Kotler, P. (2001). Upravljanje marketingom: analiza, planiranje, primjena $i$ kontrola, deveto izdanje, prijevod, Zagreb: MATE

19. Laws, E. (1995). Tourist destination management: issues, analysis and policies, London: Routledge

20. Lee, C.-K., Yoon, Y.-S., Lee, S.-K. (2007). Investigating the relationships among perceived value, satisfaction, and recommendations: The case of the Korean DMZ, Tourism Management, 28, 204-214.

21. Mathwick, C., Malhotra, N., Rigdon, E., (2001). Experiential value: conceptualization, measurement and application in the catalog and Internet shopping environment, Journal of Retailing, 77, 39-56.

22. Murphy, P., Pritchard, M.P., Smith, B. (2000). The destination product and its impact on traveller perceptions, Tourism Management, 21, 43-52.

23. Oh, H. (1999). Service quality, customer satisfaction, and customer value: A holistic perspective, Hospitality Management, 18, 67-82.

24. Oppermann, M. (2000). Tourism Destination Loyalty, Journal of Travel Research, 39, 78-84.

25. Parasuraman, A., Grewal, D. (2000). The impact of technology on the quality-value-loyalty chain: A research agenda. Journal of Academic of Marketing Science, 28, 168-174.

26. Petrick, James F. (2004). The Role of Quality, Value, Satisfaction in Predicting Cruise Passengers' Behavioral Intentions. Journal of Travel Research, 42, 397-407.

27. Petrick, J.F., Morais, D.D., Norman, W.C. (2001). An examination of the determinants od entertainment vacationers' intentions to revisit, Journal of Travel Research, 40, 41-48.

28. Pike, S. (2004). Destination marketing organisation, London: ELSEVIER

29. Pizam, A, Ellis, T. (1999). Customer satisfaction and its measurement in hospitality enterprises, International Journal of Contemporary Hospitality Management, 11 (7), 326-339.

30. Ritchie, J.R.B., Crouch, G.I. (2003). The competitive destination: A sustainable tourism perspective, London: CABI publishing 
31. Sanchez, H., Callarisa, L., Rodriguez, R.M., Moliner, M.A. (2006). Perceived value of the purchase of a tourism product, Tourism Management, 27, 394-409

32. Tam, Jackie L.M. (2004). Customer satisfaction, service quality and perceived value: an integrative model, Journal of Marketing Management, 20, 897-917.

33. Tribe, J., Snaith, T. (1998). From SERVQUAL to HOLSAT: holiday satisfaction in Varadero, Cuba, Tourism Management, 19 (1), 25-34.

34. Troung, T.-H., Foster, D., (2006). Using HOLSAT to evaluate tourist satisfaction at destinations: the case of australian holidaymakers in Vietnam, Tourism Management, 27, 842-855.

35. UNWTO, (2011) Tourism Highlights 2011 Edition, Madrid: World Tourism Organization (internet) dostupno na: www.e-unwto.org/content/ $\mathrm{u} 2+7062 /$ fulltext?p=ef08e0cc0d6a4d8a8795e242921548c3\&pi=0\#sectio$\mathrm{n}=918160$ \&page $=1 \&$ locus $=48$

36. Van der Haar, J.W., Kemp, R.G.M., Omta, O. (2001). Creating value that cannot be copied, Industrial Marketing Management, 30, 627-636.

37. Williams, P., Soutar, G.N. (2009). Value, satisfaction and behavioural intentions in an adventure tourism context, Annals of Tourism Research, 36 (3), 413-438.

38. Williams, P. Soutar, G., Ashill, N.J., Naumann, E. (2017). Value drivers and adventure tourism: A comparative analysis of Japanese and Western consumers, Journal of Service Theory and Practice, 27 (1), 102 - 122.

39. Woodruff, R.B. (1997). Customer value: The next source for competitive advantage, Journal of the Academy of Marketing Science, 25 (2), 139-153.

40. Woodruff, R.B., Gardial, S.E. (1996). Know your customer: New approaches to understanding customer value and satisfaction, Cambridge: Blackwell Publishers Inc.

41. Yuksel A. (2001). Managing customer satisfaction and retention: A case of tourist destinations, Turkey, Journal of Vacation Marketing, 7 (2), 153- 168.

42. Yuksel, A., Yuksel, F. (2001). Comparative performance analysis: Tourists' perceptions of Turkey relative to other tourist destination, Journal of Vacation marketing, 7 (4), 333-355. 


\title{
Irena Pandža Bajs, PhD
}

Faculty of Economics and Business Zagreb, University of Zagreb, Zagreb, Croatia ipandza@efzg.hr

\section{DETERMINANTS OF TOURIST DESTINATION MARKETING MANAGEMENT}

Received: April 23, 2019

Accepted: September 30, 2019

\section{Preliminary communication}

\begin{abstract}
Successful marketing management of tourist destinations results with the value that tourists expect and want which further lead to satisfaction and positive intentions of future behaviors in the context of re-arrival or recommendations to friends and family to visit that destination. For each destination it is important to define how the tourist perceives the value of tourist destination offer and which features determine the level of perceived value of current and potential tourists. The analysis of these factors provides guidance on how to improve the existing tourist offer and how should look a future offer that would increase the perceived value to improve the tourists satisfaction and achieve more solid and long-term relationships with them. The purpose of this paper is to systematically analyze relevant knowledge and understanding of the perceived value for tourists, their satisfaction and the intention of future behavior, resulting with a marketing model and guidelines for creating a successful marketing strategy for a tourist destination.
\end{abstract}

Keywords: marketing of tourist destination, perceived value, satisfaction, loyalty JEL: Z3 